УДК 378.1:61

\title{
ДОКТРИНА ВЕДЕННЯ НАВЧАЛЬНОГО ПРОЦЕСУ У ДЕРЖАВНИХ ВИЩИХ МЕДИЧНИХ НАВЧАЛЬНИХ ЗАКЛАДАХ ЗГІДНО 3 КРЕДИТНО-МОДУЛЬНОЮ СИСТЕМОЮ
}

А. Д. Беденюк

ДВНЗ “Тернопільський держсавний медичний університет імені І. Я. Горбачевського МОЗ України”

\author{
THE DOCTRINE OF REFERENCE OF THE EDUCATIONAL \\ PROCESS IN STATE HIGHER MEDICAL EDUCATIONAL \\ ESTABLISHMENTS ACCORDING TO THE CREDIT TRANSFER \\ SYSTEM
}

\author{
A. D. Bedenyuk \\ SHEI "Ternopil State Medical University by I. Ya. Horbachevsky of MPH of Ukraine"
}

\begin{abstract}
У статті наведені основні критерії та переваги впровадження кредитно-модульної системи у навчальний процес вищих медичних навчальних закладів.

The article contains the basic criteria and benefits of credit-transfer system in the educational process of medical universities.
\end{abstract}

Вступ. Інтеграційні процеси в науці та освіті сприяють підвищенню ефективності процесів пізнання, викладання, підготовки спеціалістів і є невід’ємною частиною Свропейського вибору України. Тому запровадження кредитно-модульної системи (КМС) організації навчального процесу дозволяє вдосконалити підготовку спеціалістів.

Основна частина. Медицина являс собою велику і глибоко диференційовану галузь науки. У зв'язку із застосуванням у системі охорони здоров'я новітніх технологій, у сучасній медицині відбувається міждисциплінарна інтеграція та синтез теоретичних, експериментальних і клінічних досліджень, а також досліджень у галузі профілактики. Сучасний лікар повинен володіти системним, діалектичним мисленням, синтезувати знання на різних рівнях вивчення хворого. Тому в системі вищої медичної освіти ідея міждисциплінарної інтеграції, міждисциплінарного комплексного підходу в даний час $є$ найбільш перспективною.

У зв'язку з впровадженням у вищих медичних навчальних закладах України Болонської системи навчання змінився і підхід до даного питання $[1,4]$. Мова йде про принципово нову організацію навчального процесу, при якій студенти-медики вивчають не окремі дисципліни, а окремі органи чи системи організму комплексно. Впровадження системного методу викладання (c) А. Д. Беденюк тягне за собою необхідність увести суттєві зміни в організацію навчального процесу, потребує розробки принципово нових інтегрованих навчальних програм, підготовки викладацького складу, що володіє методами системного навчання. Реалізація міжпредметного навчання в представленому вище контексті у вітчизняних медичних ВНЗ $є$ перспективним завданням, оскільки потребує радикальних організаційних, змістових і методичних реформ. Для підвищення рівня викладання та узагальнення сприйняття інформації, що викладається в програмі вищоїшколи, використовується узагальнена схема викладання клінічної дисципліни $[2,3,6]$. Мета узагальненої схеми викладання клінічної дисципліни полягає в оптимізації оволодіння клінічним мисленням, наочності та стислості інформації, упорядкуванні значення кожної дисципліни, що викладається в медичному ВНЗ.

Основне завдання міждисциплінарної інтеграції полягає в тому, щоб при вивченні певної теми активізувати й актуалізувати раніше засвоєні знання, навички та вміння, необхідні для вивчення даної теми, враховуючи при цьому інтереси наступних предметів [5].

Кредитно-модульна організація навчання за своєю суттю є гуманістичною. Вона базується на засадах суб'єктно-суб'єктної, толерантної, партнерської педагогіки. Траєкторію свого навчання, індивідуальну 
програму своєї освіти визначає студент $з$ допомогою викладача-тьютора (опікуна). Навчання має рівномірно розподілений, рівномірно напружений характер упродовж усього терміну перебування студента у вищому навчальному закладі. І найголовніше, ця система гарантує високу якість підготовки, а значить, убезпечує студента від професійної непридатності після завершення навчання.

Модернізація навчального процесу в руслі вимог Болонської декларації передбачає значне збільшення обсягів самостійної роботи студента (до 50-60%), індивідуалізацію навчання, що, відповідно, потребує належного науково-методичного забезпечення навчального процесу, відповідної матеріальної бази, поліпшення фінансово-побутового становища студента.

Усі ці зміни вимагають від науково-педагогічних працівників ВНЗ грунтовних знань, умінь і компетентності в організації своєї діяльності на новій методичній і технологічній базі - кредитно-модульній трансферній накопичувальній системі навчання.

Оцінка практичних навичок студента є важливою складовою професійної підготовки лікаря. Окремо проводиться оцінка вміння вирішувати ситуаційні задачі, що потребує не лише знання теоретичних основ, але й здатність до логічного мислення, аналізу інформації, спроможність робити узагальнення. Впровадження КМС оцінки знань студентів у навчальний процес має велике значення в підвищенні якості теоретичних знань і набутих практичних навичок студентів, оскільки стимулює їх до осягнення спеціальності, в тому числі в самостійній роботі, в прагненні отримати найбільшу кількість балів. Студенти фактично не пропускають практичні заняття, сумлінно

\section{Лiтература}

1. Вороненко Ю. В. Шляхи наближення вищої медичної освіти в Україні до міжнародних стандартів / Ю. В. Вороненко // Укр. мед. вісті. - 1997. - Т. 1. -С. 59-60.

2. Інтеграція навчального процесу-основа ефективності кредитно-модульної системи навчання / П. О. Неруш, О. Г. Родинський, О. В. Мозгунов [та ін.] // Мед. освіта. 2008. - №4.-C. 16-17.

3. Мілерян В. С. Методичні основи підготовки та проведення навчальних занять в медичних вузах : [методичний посібник] / В. С. Мілерян. - К. : НМУ, 2004. - 80 с.

4. Підаєв А. В. Болонський процес в Свропі / А. В. Підаєв, В. Г. Передерій. -Одеса:Одес. держ. мед. ун-т, 2004. - 192 с.

5. Самостійна робота студентів при вивченні анатомії людини в світлі Болонського процесу / Б. В. Шутка, Я. І. Клипич, О. В. Саган [та ін.] // Матеріали навч.-метод. конф. ["Перші результати та перспективи реформування системи медичної освіти в Україні”], (Запоріжжя, 1-2 черв- готуються й активно працюють, своєчасно виконують завдання самостійної роботи. У кінцевому результаті застосування КМС оцінки знань студентів спрямовано на отримання освіти високої якості та диплома $з$ переважним правом отримання престижної і бажаної роботи [7-9].

Підсумовуючи вищевказане, можна дійти висновку, що кредитно-модульна система:

- дає можливість систематично одержувати докладну інформацію про виконання кожним студентом графіка самостійної роботи;

- забезпечує постійний зворотний зв'язок і дає змогу здіснювати оперативні виховні і дидактичні заходи;

- реалізує диференційований, індивідуальний підходи у роботі зі студентами;

- підвищує точність та об'єктивність оцінки успішності навчання;

- дозволяє бути не “передавачем” інформації 3 дисципліни, а помічником студентів у набутті знань.

Висновок. Впровадження кредитно-модульної системи є нагальними завданнями системи вищої освіти України на шляху приєднання до Болонського процесу. Реалізація цих завдань вимагатиме розробки нових організаційних, методичних і нормативних засад щодо проведення навчального процесу у вищих навчальних закладах, перегляду методики розрахунку навантаження викладачів (можлива також система кредитів і для викладачів), яка має врахувати аудиторну роботу, розробку нових курсів, впровадження інформаційних технологій, перевірку письмових робіт та інші види діяльності, які забезпечуватимуть самостійну роботу студентів та контроль їх знань.

ня 2006 р.; тези допов.). - Запоріжжя, 2006. - С. 248-249.

6. Скопенко В. В. Виступ на регіональній нараді з питань атестації наукових і науково-педагогічних кадрів 26.20.1999 p. / В. В. Скопенко // Бюл. ВАКу України. - 1999. -№ 6. - С. 4-10.

7. Система управління якістю медичної освіти в Україні / [І .Є. Булах, О. П. Волосовець, Ю. В. Вороненко та ін.]. Дніпропетровськ : Артпрес, 2003.-211 с.

8. Кредитно-модульна система та досвід впровадження іiі елементів на кафедрах, що вивчають інфекційні хвороби / Т. Є. Онищенко, Т. М. Пахольчук, О. В. Рябоконь [та ін.] // Запорож. мед. журн. - 2008. - № 1. - С. 179-181.

9. К вопросу о совершенствовании методов контроля знаний студентов медицинского факультета в условиях кредитно-модульной системы обучения / Н. И. Романенко, Н. В. Крисанова, Р. Ф. Каптюх [и др.] // Запорож. мед. журн. -2007. - №3.-С. 158-160. 